\title{
Development of an open-tubular trypsin reactor for on-line digestion of proteins
}

\author{
E. C. A. Stigter • G. J. de Jong • W. P. van Bennekom
}

Received: 20 June 2007 /Revised: 6 August 2007 / Accepted: 24 August 2007 / Published online: 22 September 2007

(C) Springer-Verlag 2007

\begin{abstract}
A study was initiated to construct a micro-reactor for protein digestion based on trypsin-coated fused-silica capillaries. Initially, surface plasmon resonance was used both for optimization of the surface chemistry applied in the preparation and for monitoring the amount of enzyme that was immobilized. The highest amount of trypsin was immobilized on dextran-coated SPR surfaces which allowed the covalent coupling of $11 \mathrm{ng} \mathrm{mm}^{-2}$ trypsin. Fused-silica capillaries were modified in a similar manner and the resulting open-tubular trypsin-reactors having a $\mathrm{pH}$ optimum of $\mathrm{pH} 8.5$, display a high activity when operated at $37{ }^{\circ} \mathrm{C}$ and are stable for at least two weeks when used continuously. Trypsin auto-digestion fragments, sample carry-over, and loss of signal due to adsorption of the protein were not observed. On-line digestion without prior protein denaturation, followed by micro-LC separation and photodiode array detection, was tested with horse-heart cytochrome $\mathrm{C}$ and horse skeletal-muscle myoglobin. The complete digestion of $20 \mathrm{pmol} \mu \mathrm{L}^{-1}$ horse cytochrome $\mathrm{C}$ was observed when the average residence time of the protein sample in a $140 \mathrm{~cm} \times 50 \mu \mathrm{m}$ capillary immobilized enzyme reactor (IMER) was $165 \mathrm{~s}$. Mass spectrometric identification of the injected protein on the basis of the tryptic peptides proved possible. Protein digestion was favorable with respect to reaction time and fragments formed when compared with other on-line and off-line procedures. These results and the easy preparation of this
\end{abstract}

E. C. A. Stigter $(\bowtie) \cdot$ G. J. de Jong • W. P. van Bennekom Division of Biomedical Analysis,

Department of Pharmaceutical Sciences, Faculty of Sciences, Utrecht University,

Sorbonnelaan 16,

3584 CA Utrecht, The Netherlands

e-mail: e.c.a.stigter@uu.nl micro-reactor provide possibilities for miniaturized enzyme-reactors for on-line peptide mapping and inhibitor screening.

Keywords Trypsin reactor · Dextran hydrogel .

Surface plasmon resonance - Liquid chromatography .

On-line digestion

\section{Introduction}

A demand for smaller enzyme reactors has emerged in recent years, as a consequence of ongoing miniaturization in the biochemical and analytical sciences. These micro-reactors have been used in biocatalysis and biosensing. In the field of proteomics the reactors are a tool in peptide mapping, in which proteins are identified via peptide fragment identification after proteolysis. Currently, in spite of its limitations, most of these analyses are conducted by means of 2D gel electrophoresis followed by digestion of the proteins, liquid chromatographic (LC) separation, and mass spectrometric (MS) identification of the peptides [1-3]. The most timeconsuming step in this procedure is digestion of the protein using a protease. In general, every protein to be investigated is individually incubated with the protease at a concentration of approximately $1-2 \%$ protein weight for 2 to $18 \mathrm{~h}$ at an elevated temperature (typically $37{ }^{\circ} \mathrm{C}$ ). In addition to the long incubation time needed, a certain level of auto-digestion of the protease can be expected. To reduce sample handling, digestion time, and the risk of sample contamination, methods for the on-line digestion of proteins have been developed that use proteases immobilized on a solid support.

Immobilized enzyme reactors have been developed and used over the years for several industrial and analytical purposes [4-6]. An obvious benefit for immobilizing 
biocatalysts is the fact that the enzyme can be used in several catalytic cycles and that both catalyst and reaction mixture can easily be separated. Moreover, immobilized enzymes generally show an improved stability even at more extreme reaction conditions. Several procedures have been developed for immobilization of enzymes, e.g. adsorption or encapsulation in a matrix or membrane. Alternatively, and more often used, is the covalent attachment of biocatalysts to carrier materials, which allows the immobilization of a large amount of enzyme for a high activity per surface area. Generally, particulate large-pore carrier materials are used, such as controlled-pore glass [7, 8], silica [9], or polymers like the commercially available poroszyme [10-12]. Current research in the production of immobilized enzymes is focused on the use of monolithic materials, as they enable efficient fragmentation of proteins [13-17]. Although both commercially available and self-prepared reversed-phase capillary monolithic columns have successfully passed reproducibility assessment [18, 19], synthesis of monoliths suitable for small-scale enzyme reactors can still be troublesome. Materials suitable for the fabrication of larger-scale enzyme reactors are commercially available from BIA Separations (Ljubljana, Slovenia).

Although it is possible to apply an immobilized enzyme reactor (IMER) positioned after the separation column [20], most papers dealing with on-line digestion of protein samples position the IMER upstream of the separation column. In these cases the sample is first digested and the resulting peptide fragments are separated and identified by LC-MS. This approach is often employed in multi-dimensional LC methods [13, 21, 22], and has also found application in peptide mapping using capillary electrophoresis [23, 24]. Alternatively, as recently shown by Zhao et al. [25] and Krenkova et al. [26], who covalently coupled trypsin to the wall of fused-silica nanoelectrospray emitters, a protein sample can be analyzed by direct infusion into a mass spectrometer.

This paper describes the development of trypsin-modified open-tubular micro-reactors. The chemistry was controlled and optimized using surface plasmon resonance (SPR), a technique allowing sensitive and real-time monitoring of surface reactions such as protein binding [27]. The surface modification resulting in the highest enzyme immobilization yield, was used to covalently immobilize the trypsin on the inside wall of a fused-silica capillary. The constructed trypsin micro-reactor, which is compatible with micro- and nano-LC, was further characterized. The influence of reaction time, $\mathrm{pH}$, temperature, and reactor stability were investigated with the model substrate insulin B-chain. The reactor was also applied to digestion of the proteins cytochrome $\mathrm{C}$ and myoglobin. The produced peptides were analyzed by liquid chromatography-mass spectrometry.

\section{Experimental}

\section{Materials}

The SPR equipment used was from IBIS Technologies (currently available from Eco Chemie, Utrecht, The Netherlands) equipped with a $200-\mu \mathrm{L}$ polycarbonate cuvet. The gold-sensor disks, purchased from SSENS (Hengelo, The Netherlands), were positioned on the IBIS-prism using index-matching oil from R.P. Cargille Laboratories (Cedar Grove, USA). PEEK nuts, unions, tubing, and loops were from Upchurch (Santa Monica, USA). Manual injections during the preparation of the reactors were performed using a Rheodyne 7010 injector (Inacom, Veenendaal, The Netherlands) equipped with a $1-\mathrm{mL}$ PEEK loop. Model 10ADvp HPLC pumps from Shimadzu (Kyoto, Japan) were used for reactor preparation and activity determinations. The water used for washing and to prepare buffers was produced by a Sartorius Arium 611 ultrapure water system (Nieuwegein, The Netherlands; conductivity $>18.2 \mathrm{M} \Omega \mathrm{cm}$ ). The model ABS759A UV absorbance detector was equipped with a capillary flow-cell $(75-\mu \mathrm{m}$ i.d.) and was obtained from Applied Biosystems (Nieuwerkerk a/d IJssel, The Netherlands).

On-line digestion experiments with micro-HPLC separations were conducted using LC-Packings instruments and columns (Amsterdam, The Netherlands). The equipment consisted of an injector (Famos), nanovalve column switcher (Switchos), nanopump (Ultimate), and a photodiode-array detector (PDA) equipped with a micro flow cell $(45 \mathrm{~nL})$. The reversed-phase pre-columns were $5 \times 0.3 \mathrm{~mm}$ with 5 - $\mu \mathrm{m} 100 \AA \mathrm{C}_{18}$ particles. The $150 \times 0.3 \mathrm{~mm}$ reversedphase micro-column contained 3- $\mu \mathrm{m} 100 \AA \mathrm{C}_{18}$ PepMap particles. The mass spectrometer was an Agilent LC/MSD XCT ion trap (Amstelveen, Netherlands).

Acetic acid, boric acid, calcium chloride $\left(\mathrm{CaCl}_{2}\right)$, ethanol, ethanolamine (EA), hydrochloric acid $(\mathrm{HCl})$, hydrogen peroxide, sodium dihydrogen phosphate, sodium chloride, sodium hydroxide $(\mathrm{NaOH})$, and sulfuric acid were purchased from Merck (Darmstadt, Germany). HPLC grade acetonitrile and ethanol were from Biosolve (Valkenswaard, The Netherlands). 4-(2-Hydroxyethyl)-1-piperazineethanesulfonic acid (HEPES), tris-hydroxymethylaminoethane (TRIS), urea, and acetone were purchased from Acros Organics (Geel, Belgium). Benzamidin, $\mathrm{N}$-(3-dimethylaminopropyl)- $\mathrm{N}$ ethylcarbodiimide hydrochloride (EDC), benzoyl-arginine ethyl ester (BAEE), iodoacetamide, $N$-hydroxysuccinimide (NHS), and carboxyl-modified dextran (CMD) were purchased from Fluka (Buchs, Switzerland). Horse-heart cytochrome C, insulin B (oxidized), polyoxyethylenesorbitan monolaurate (Tween 20), and porcine pancreas trypsin were purchased from Sigma (St Louis, USA). The specific activity of trypsin was determined according to the method of Schwert 
and Takenaka [28] using BAEE as substrate and turned out to be $14700 \mathrm{U} \mathrm{mg}^{-1}$. Aminopropyltriethoxysilane (APTES), carbonyl diimidazole (CDI), glycidoxypropyltrimethoxysilane (GOPS), and mercaptoethanol (ME) were from Aldrich Chemical Company (Milwaukee, USA). Amino-modified dextran (AMD) was from Unavera ChemLab (Mittenwald, Germany). Fused-silica capillaries were purchased from Bester (Mijdrecht, The Netherlands).

Piranha solution was prepared by mixing 1 part $30 \%$ hydrogen peroxide and 6 parts concentrated sulfuric acid (caution, aggressive solution). TRIS digestion buffer consisted of $50 \mathrm{mmol} \mathrm{L}^{-1}$ TRIS and $1 \mathrm{mmol} \mathrm{L}^{-1} \mathrm{CaCl}_{2}$ adjusted to $\mathrm{pH} 8.2$ by use of $1 \mathrm{~mol} \mathrm{~L}^{-1} \mathrm{HCl}$ solution.

Methods

Preparation of dextran-coated SPR sensor disks (Fig. 1)

The SPR sensor disks were extensively cleaned in freshly prepared piranha solution. After $1 \mathrm{~h}$ the disks were thoroughly rinsed with water, dried in a stream of nitrogen gas, and immediately incubated for $6 \mathrm{~h}$ in a $10 \mathrm{mmol} \mathrm{L}^{-1}$ solution of $\mathrm{ME}$ in ethanol in order to produce a selfassembled monolayer (SAM) containing hydroxyl functionalities. After SAM formation, the disks were washed with ethanol and water, and dried with nitrogen gas. The resulting $\mathrm{ME}$ disks were incubated for $1 \mathrm{~h}$ with a $10 \%$ GOPS solution in $98 \%$ ethanol after which the disks were washed with ethanol, dried with nitrogen gas and stored overnight at $50{ }^{\circ} \mathrm{C}$.

Dextran-modified sensors were prepared by incubating GOPS-modified sensor disks for $20 \mathrm{~h}$ at room temperature with a $10 \%$ AMD solution in a $50 \mathrm{mmol} \mathrm{L}^{-1}$ borate buffer, $\mathrm{pH}$ 9.5. After removing the solution the disks were washed with water, ethanol, and water, dried in a gentle flow of nitrogen gas, and stored at room temperature in a closed box until use.

Alternatively, ME disks were incubated for $1 \mathrm{~h}$ with a $10 \%$ APTES solution in acetone. After washing, drying, and storing overnight in the oven, similar to the GOPS disks, the surfaces were incubated for $1 \mathrm{~h}$ with a solution containing $5 \% \mathrm{CMD}$ in water containing $200 \mathrm{mmol} \mathrm{L}^{-1} \mathrm{EDC}$ and $50 \mathrm{mmol} \mathrm{L}^{-1} \mathrm{NHS}$. After removing the solution, the disks were washed with water and ethanol, and incubated for $15 \mathrm{~min}$ in a solution containing $100 \mathrm{mmol} \mathrm{L}^{-1} \mathrm{CDI}$ in acetone. These activated surfaces were washed with ethanol, blown to dryness with nitrogen, and incubated overnight with a solution of $10 \%$ AMD in water. After removing the solution the disks were washed with water, ethanol, and water, dried in a gentle flow of nitrogen gas, and stored at room temperature in a closed box until use.

\section{SPR experiments}

The GOPS-modified SPR sensor disks were incubated overnight with $200 \mu \mathrm{L}$ of a solution containing $2.5 \mathrm{mg} \mathrm{mL}^{-1}$ trypsin and $50 \mu \mathrm{g} \mathrm{mL}^{-1}$ benzamidin in $50 \mathrm{mmol} \mathrm{L}^{-1}$ borate buffer, pH 9.5 (Fig. 1a). Both types of dextran-modified sensor disk were activated for $60 \mathrm{~min}$ with $200 \mu \mathrm{L} 100 \mathrm{mmol} \mathrm{L}^{-1} \mathrm{CDI}$ in dry acetone. After washing the surface with water to remove the last traces of acetone, the sensors were incubated overnight with $200 \mu \mathrm{L} 2.5 \mathrm{mg} \mathrm{mL}^{-1}$ trypsin and $50 \mu \mathrm{g} \mathrm{mL}$ benzamidin in $50 \mathrm{mmol} \mathrm{L}^{-1}$ borate buffer, $\mathrm{pH} 8.5$ (Fig. $1 \mathrm{~b}$ and c, respectively). The remaining esters were inactivated by incubating the disks for $10 \mathrm{~min}$ with $1 \mathrm{~mol} \mathrm{~L}^{-1} \mathrm{EA}$ in $50 \mathrm{mmol} \mathrm{L}{ }^{-1}$ borate buffer, $\mathrm{pH}$ 8.5. The successive steps in the immobilization were monitored with SPR and the amount of covalently coupled enzyme was calculated from the recorded angle shift. During the experiments the SPR system was thermostatted at $25.0{ }^{\circ} \mathrm{C}$.

\section{Preparation of dextran-coated fused-silica capillaries}

In order to generate a proper surface for silanization, fusedsilica capillaries were cleaned for $30 \mathrm{~min}$ with $2 \mathrm{~mol} \mathrm{~L}^{-1}$ $\mathrm{NaOH}$ solution at a flow-rate of $5 \mu \mathrm{L} \min ^{-1}$. The capillary was then washed for 30 min with $0.1 \mathrm{~mol} \mathrm{~L}^{-1} \mathrm{HCl}$, for $5 \mathrm{~min}$ with water, and finally for $5 \mathrm{~min}$ with ethanol. In order to prepare dextran-coated capillaries, the capillaries were flushed for $60 \mathrm{~min}$ with a 10\% GOPS solution in ethanol. After this step, the capillaries were closed with silicon plugs and dried overnight at $50^{\circ} \mathrm{C}$. After silanization, the capillaries were flushed with methanol at a flow-rate of $10 \mu \mathrm{L} \mathrm{min}^{-1}$ after which the capillaries were chemically modified in flow, using injections with a Rheodyne 7010 manual injector equipped with a 1-mL PEEK loop, in a way similar to that described above in the SPR section. Washing steps were conducted at flow rates of $10 \mu \mathrm{L} \mathrm{min}{ }^{-1}$, overnight incubations at a flow rate of $1 \mu \mathrm{L} \min ^{-1}$. All chemistries are outlined in Fig. 1.

\section{Enzyme activity determination}

Insulin B chain was used as a substrate to determine the activity of trypsin. Injections of $1 \mu \mathrm{L}$ of a concentration of $20 \mu \mathrm{mol} \mathrm{L}{ }^{-1}$ in digestion buffer were introduced into the reactor that was kept at the indicated temperature using a water bath. To determine the enzyme activity in solution, trypsin was incubated in these solutions also (final trypsin concentration $0.4 \mu \mathrm{g} \mathrm{mL} \mathrm{m}^{-1}$ ). At time intervals from 0.5 to $30 \mathrm{~min}, 100-\mu \mathrm{L}$ samples were taken and the activity was stopped by the addition of $5 \mu \mathrm{L} 20 \%$ TFA in water. Buffers that were used to determine the effect of $\mathrm{pH}$ on activity were MES ( $\mathrm{pH} 5.5$ to 6.5 ), MOPS ( $\mathrm{pH} 6.5$ to 7.8 ), TRIS 
Fig. 1 Surface modifications used to immobilize the enzyme in fused-silica capillaries. a, GOPS-modified; b, GOPS/ AMD-modified; c, APTES/ CMD/AMD-modified surface. In the last case the CDI activation and enzyme $\left(\mathrm{H}_{2} \mathrm{~N}\right.$-enzyme $)$ coupling are as in $\mathbf{b}$

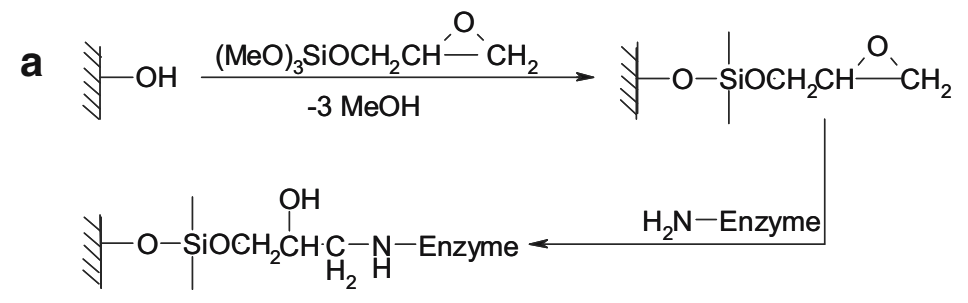

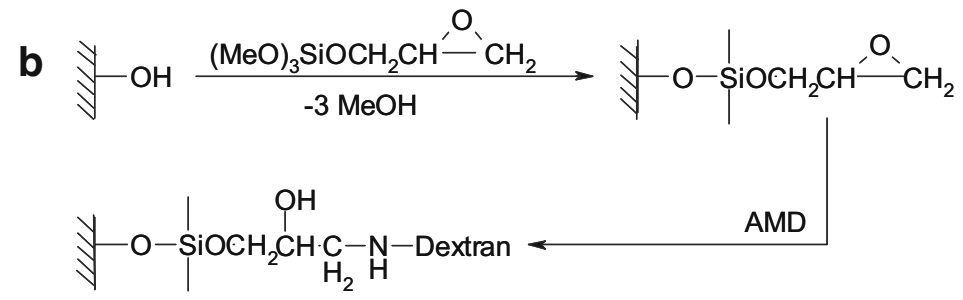

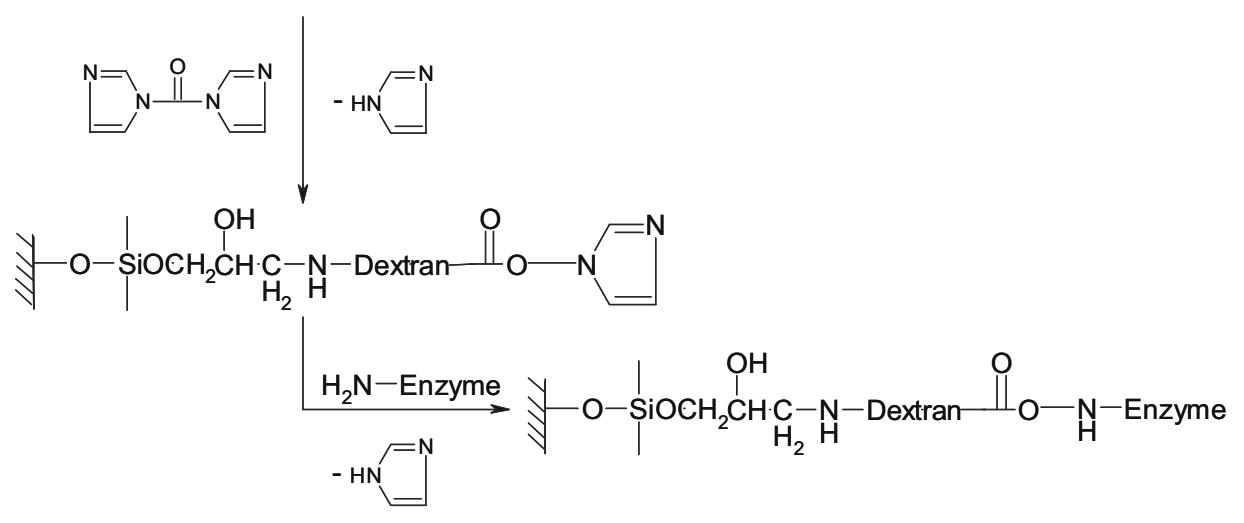

C

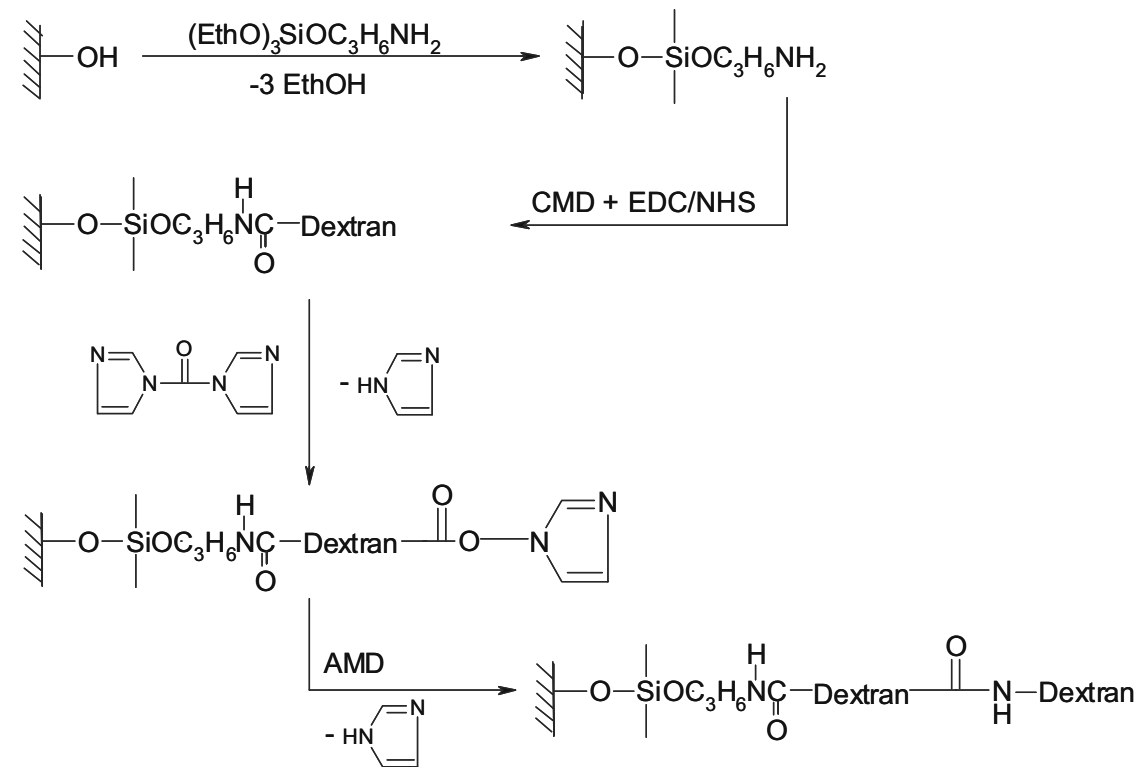

(pH 7.5 to 9), and CHES (pH 8.6 to 10.1). The buffers were adjusted to $\mathrm{pH}$ by use of $1 \mathrm{~mol} \mathrm{~L}^{-1} \mathrm{NaOH}$ and were prepared at a $50 \mathrm{mmol} \mathrm{\textrm {L } ^ { - 1 }}$ concentration, also containing $5 \mathrm{mmol} \mathrm{L}^{-1} \mathrm{CaCl}_{2}$. To determine the effect of temperature, the temperature during incubation was varied between $10^{\circ} \mathrm{C}$ and $60{ }^{\circ} \mathrm{C}$. Both the on-line and off-line samples were analyzed using micro-HPLC with PDA detection, as outlined below. The insulin B conversion of both immobilized trypsin and the enzyme in solution was calculated from the peak areas of substrate and products. 


\section{On-line protein digestion in micro-HPLC}

For the on-line peptide and protein digestion experiments the trypsin-modified capillaries were positioned between the LC injector and a 10-port valve, as shown in Fig. 2, and were immersed in a thermostatted water bath set at $37{ }^{\circ} \mathrm{C}$ unless mentioned otherwise. Protein samples were prepared in digestion buffer and were transported through the capillary towards a 10 -port valve using a $5 \%$ acetonitrile solution containing $0.05 \%$ TFA. The peptide fragments formed during digestion were concentrated on an RP trapping column (TC) and salts and other buffer components present in the sample were removed. By switching the valve the trapping column is in series with the RP micro column and an acetonitrile gradient started. The gradient was composed of two solutions: (A) $5 \%$ acetonitrile in water containing $0.05 \%$ TFA and (B) $80 \%$ acetonitrile in water containing $0.04 \%$ TFA. In $30 \mathrm{~min}$ the gradient changed linearly from 0 to $50 \% \mathrm{~B}$, followed by $10 \mathrm{~min}$ at $90 \% \mathrm{~B}$ and $20 \mathrm{~min}$ at $0 \% \mathrm{~B}$. The eluent was monitored with the PDA detector in the range from 200 to $595 \mathrm{~nm}$.

ESI-MS was conducted in the positive-ion mode with the capillary voltage set at $3500 \mathrm{~V}$. The flow rate and temperature of the nitrogen drying gas were $5 \mathrm{~L} \mathrm{~min}^{-1}$ and $325^{\circ} \mathrm{C}$, respectively. The sequence of the peptide fragments was determined by using the mass spectrometer in autoMS-MS mode fragmenting the two peptides that were most abundantly present when the signal reached threshold. The MS-MS result was analyzed by a Mascot database search (http://www.matrixscience.com).

\section{Results and discussion}

Surface chemistry and enzyme immobilization

As shown before [29], modification of an SPR sensor surface with a dextran hydrogel leads to less non-specific adsorption of proteins compared with unmodified surfaces. The presence of such a layer also enhances the immobilization capacity of biomolecules compared with monolayerbased coatings. Due to the flexible nature of the dextran chains, the accessibility also is often improved compared with molecules immobilized on a flat surface. As the amount of protein present in a capillary after immobilization cannot be determined easily, SPR sensors were used as a model to investigate the effect of the different surface modifications on the amount of trypsin that could be attached covalently. Hydroxyl functionalities necessary to enable silanization are introduced using mercaptoethanol (ME), but all other surface modifications are carried out in exactly the same way, both on the SPR sensor surfaces and in the fused-silica capillaries.

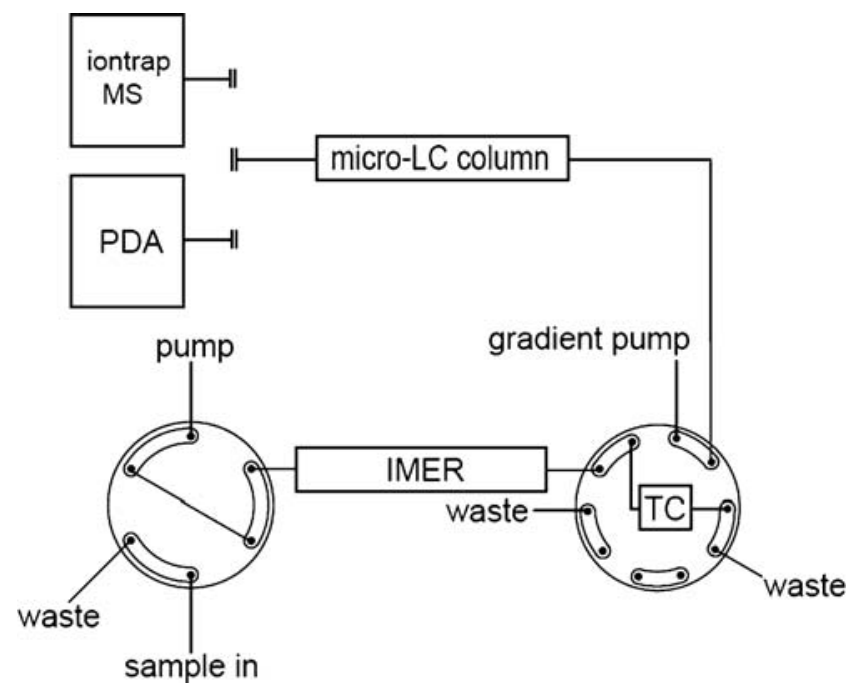

Fig. 2 Set-up used for on-line protein digestion using a trypsin-modified fused-silica capillary. For detection a PDA or an ion-trap MS was used

Trypsin immobilization after silanization with GOPS by reaction of the trypsin primary amines and the glycidyl function of GOPS results in an SPR angle shift of $350 \pm 20 \mathrm{~m}^{\circ}(n=3)$, which equals an amount of trypsin of $2.9 \pm 0.2 \mathrm{ng} \mathrm{mm}{ }^{-2}$ covalently attached to the surface, which is close to monolayer coverage of trypsin. When the GOPS-silanized surface is modified with AMD, resulting in a dextran hydrogel, the amount of trypsin that can be immobilized after CDI activation increases to $9.5 \pm 0.3 \mathrm{ng} \mathrm{mm}{ }^{-2}(n=3)$. To further increase the amount of trypsin, an intermediate dextran layer was added. Therefore, fused-silica capillaries were APTES silanized and modified with CMD and AMD, subsequently. The amount of trypsin that could covalently be attached to these layers was determined with SPR and proved to be $11.1 \pm$ $0.5 \mathrm{ng} \mathrm{mm}^{-2}(n=2)$. As this amount is significantly more than obtained with the GOPS/AMD surface, all further experiments have been conducted with fused-silica capillaries the surface of which is modified with dextran in this way.

Assuming that the investigated surface modification allows a similar amount of trypsin to be immobilized per surface area in fused-silica capillaries, the quantity of enzyme immobilized on the dextran-modified capillaries is more than five times larger per surface area compared with other open-tubular, trypsin micro-reactors described in the literature [23, 30-32]. These reactors, first described by Amankwa and Kuhr [30], are based on immobilized avidin and, at saturation, 6.5 pmol biotinylated trypsin was immobilized in a $50-\mathrm{cm}$ long capillary of $50-\mu \mathrm{m}$ i.d.. This amount equals $2 \mathrm{ng}$ trypsin $\mathrm{mm}^{-2}$ capillary surface, which is less than monolayer coverage.

\section{Characterization of the enzyme reactor}

Fused-silica capillaries were modified with dextran as described above and the activity and characteristics of the 
a

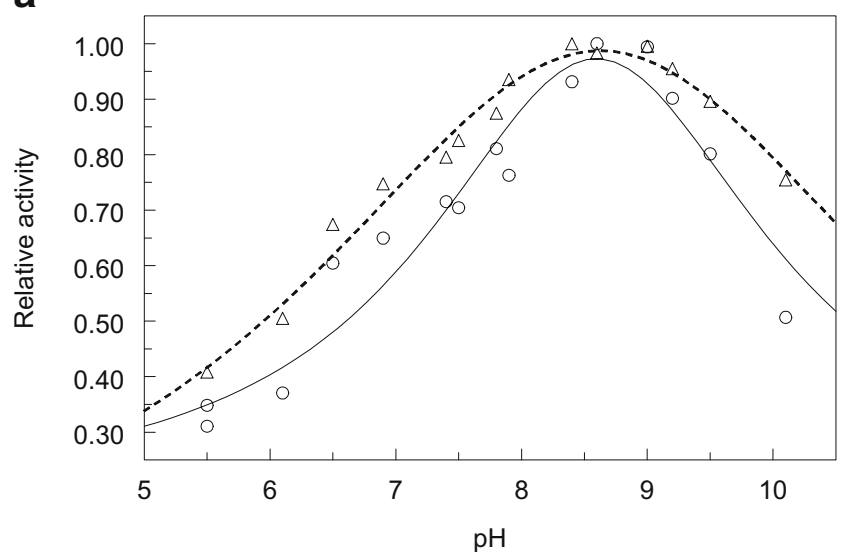

b

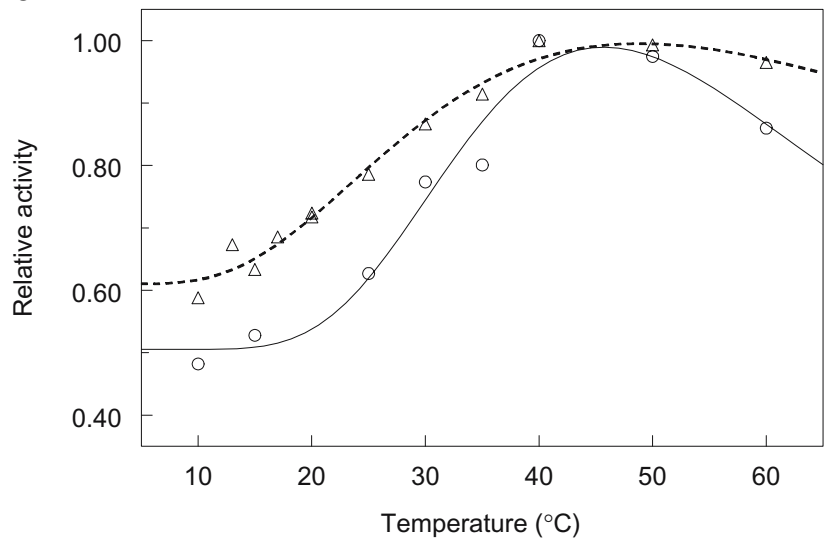

Fig. 3 Effect of (a) $\mathrm{pH}$ and (b) temperature on the relative activities of trypsin in solution (circles) and trypsin immobilized on an APTES/ CMD/AMD-modified fused-silica surface (triangles). In $\mathbf{b}$ the maximum insulin $\mathrm{B}$ conversion rate determined under experimental conditions is $4.41 \pm 0.02 \mathrm{pmol} \mathrm{min}^{-1} \mu \mathrm{g}^{-1}$ for the enzyme in solution and $12.32 \pm 0.35 \mathrm{pmol} \mathrm{min}^{-1} \mu \mathrm{g}^{-1}$ for a $3-\mu \mathrm{L}, 50-\mu \mathrm{m}$ i.d. microreactor operated at a flow rate of $1 \mu \mathrm{L} \mathrm{min}{ }^{-1}$

trypsin micro-reactor were assessed with the oligopeptide insulin B chain, a 30 amino acids long insulin fragment. When insulin B is exposed to the enzyme present in the reactor, hydrolysis at the arginine present at position 22 and, to a lesser extent, the lysine at position 29 is observed. Using the aforementioned substrate insulin $\mathrm{B}$, the $\mathrm{pH}$ optimum was determined for the enzyme in solution and the immobilized enzyme. As can be observed in Fig. 3a, the optimum $\mathrm{pH}$ value for both free and immobilized trypsin is $\mathrm{pH}$ 8.5. Therefore, all further experiments are conducted at this $\mathrm{pH}$ value.

Also the effect of temperature on the activity of both the immobilized trypsin and the enzyme in solution was determined in the range $10{ }^{\circ} \mathrm{C}$ to $60{ }^{\circ} \mathrm{C}$. As can be observed in Fig. 3b, the activity of trypsin increases with temperature to reach a maximum around $40{ }^{\circ} \mathrm{C}$ and decreases at higher temperatures. The immobilized enzyme shows a higher activity compared with the enzyme in solution, which may be due to an often observed higher stability of immobilized enzymes, also under more extreme conditions. From the data the activation energy can be determined. For the immobilized enzyme a value of $12.2 \pm$ $0.3 \mathrm{~kJ} \mathrm{~mol}^{-1}$ can be calculated and for the enzyme in solution a value of $17.2 \pm 0.5 \mathrm{~kJ} \mathrm{~mol}^{-1}$. This means that for the immobilized enzyme the temperature has less effect on the activity than for the enzyme in solution. As the highest activity is observed at $37{ }^{\circ} \mathrm{C}$, all further experiments are conducted at that temperature.

For the enzyme in solution a specific activity of $4.41 \pm$ $0.02 \mathrm{pmol} \mathrm{min}^{-1} \mu \mathrm{g}^{-1}$ is determined at a concentration of 20 pmol $\mu \mathrm{L}^{-1}$ insulin $\mathrm{B}$ and $\mathrm{pH} 8.5$ and $37^{\circ} \mathrm{C}$. Under similar conditions, in a microreactor of $3 \mu \mathrm{L}$ with a $50 \mu \mathrm{m}$ i.d. and operated at a flow rate of $1 \mu \mathrm{L} \mathrm{min}{ }^{-1}$, an amount of $12.32 \pm 0.35 \mathrm{pmol}$ insulin B is converted. In such a reactor a total of $2.67 \mu \mathrm{g}$ trypsin might be present taking the earlier SPR observations into account, which means that the immobilized enzyme is both accessible and still active after immobilization. The specific activity after immobilization is higher than observed in recent papers for the protease pepsin immobilized on beaded chitosan [33, 34] and trypsin photoimmobilized in a fused-silica capillary [34].

The stability during operation of the open-tubular reactor was tested at $37{ }^{\circ} \mathrm{C}$ and $\mathrm{pH} 8.5$. Activity tests using the model substrate show that the activity of a reactor that is continuously in operation, is constant for at least two weeks. The enzyme trypsin dissolved in digestion buffer and incubated for $24 \mathrm{~h}$ at $37{ }^{\circ} \mathrm{C}$ loses $60 \%$ of its activity, and after three days no activity is measured.

On-line digestion of proteins

The on-line digestion of horse cytochrome $\mathrm{C}$ is accomplished as described in the Methods section. Samples are

Table 1 Summary of the on-line digestion experiments for cytochrome $\mathrm{C}$. The experiments were conducted at $\mathrm{pH} 8.5$ and $37^{\circ} \mathrm{C}(n=3)$

\begin{tabular}{llllll}
\hline capillary & $\begin{array}{c}\text { reactor } \\
\text { ID }(\mu \mathrm{m})\end{array}$ & \multicolumn{2}{c}{$\begin{array}{c}\text { amount injected } \\
(\mu \mathrm{L})\end{array}$} & $\begin{array}{c}\text { digestion } \\
\text { time }(\mathrm{s})\end{array}$ & $\begin{array}{c}\text { \% undigested } \\
\text { protein }(\mathrm{SD})\end{array}$ \\
\hline 75 & 1 & 248 & 20 & 60 & $65.9(4.8)$ \\
75 & 1 & 124 & 10 & 60 & $35.8(3.4$ \\
75 & 1 & 12.4 & 10 & 60 & $23.6(1.3)$ \\
50 & 1 & 248 & 20 & 60 & $14.0(1.9)$ \\
50 & 1 & 124 & 10 & 60 & $2.3(2.0)$ \\
50 & 2.75 & 248 & 20 & 165 & 0 \\
50 & 2.75 & 124 & 10 & 165 & 0 \\
50 & 2.75 & 12.4 & 10 & 165 & 0 \\
\hline
\end{tabular}

The experiments were conducted at $\mathrm{pH} 8.5$ and $37^{\circ} \mathrm{C}(n=3)$ 
submitted to on-line digestion in a 22-cm long trypsinmodified APTES/CMD/AMD-coated capillary with an i.d. of $75 \mu \mathrm{m}$ (total volume $1 \mu \mathrm{L}$ ) or with an i.d. of $50 \mu \mathrm{m}$ and a length of $51 \mathrm{~cm}(1 \mu \mathrm{L})$ or $140 \mathrm{~cm}(2.75 \mu \mathrm{L})$. When the protein is not reduced, the heme-moiety will remain covalently attached to the peptides containing the protein sulfhydryls. By monitoring the heme-containing peptides at $395 \mathrm{~nm}$, the progress of the digestion and the amount of undigested protein can be determined. The results are summarized in Table 1.

As expected when a limited amount of enzyme activity is present in a reactor $(22 \mathrm{~cm} \times 75 \mu \mathrm{m})$, for increasing concentrations cytochrome $\mathrm{C}$ a larger amount of protein is undigested. Nevertheless, many tryptic peptides are still generated. As can be expected, an increase in exposure time of the substrate with the immobilized enzyme will result in an improved digestion yield. A longer contact time is achieved by increasing the reactor volume by using a longer enzymemodified capillary. Additionally, the enzyme-to-substrate ratio is increased, which is accomplished by changing the surfaceto-volume ratio by using a capillary with a smaller internal diameter. As can be observed in Table 1, decreasing the i.d. of the capillary leads to improved digestion for a reactor of equal volume due to a higher surface-to-volume ratio and hence a higher amount of enzyme. The use of a $140 \mathrm{~cm} \times$ $50 \mu \mathrm{m}$ capillary allows the complete digestion of up to 20 pmol $\left(248 \mu \mathrm{g} \mathrm{mL}^{-1}\right)$ of cytochrome $\mathrm{C}$ in less than $5 \mathrm{~min}$ including the sample concentration and removal of salts by the trapping column.

Chromatograms for the on-line digestions obtained with capillaries with an i.d. of $50 \mu \mathrm{m}$ are shown in Fig. 4. Figure 4a shows a blank run in a capillary containing no enzyme and Fig. $4 \mathrm{~b}$ and c present on-line digestions for a microreactor of $2.75 \mu \mathrm{L}$ operated at $5 \mu \mathrm{L} \mathrm{min}{ }^{-1}$ and $1 \mu \mathrm{L} \mathrm{min}{ }^{-1}$, respectively. As discussed above, incomplete digestion of the injected cytochrome $\mathrm{C}$ will lead to the presence of multiple peptide fragments containing the heme group, as is visible in Fig. 4b. The digestion is complete when the sample exposure time is $165 \mathrm{~s}$ (flow rate $1 \mu \mathrm{L} \min ^{-1}$ ) as both intermediate products and the undigested protein (retention time $44 \mathrm{~min}$ in Fig. 4a), which are visible at a wavelength of $395 \mathrm{~nm}$ as outlined above, are no longer observed. An injection of off-line-digested cytochrome C showed a similar chromatogram as is shown in Fig. 4c.

The on-line digestion of horse cytochrome $\mathrm{C}$ is also monitored with mass spectrometry. The effect of flow rate and hence incubation time on the digestion of the protein and the number of peptides identified with a Mascot database search is determined and summarized in Table 2. In this table the undigested amounts of protein which have been determined using the PDA detector are also shown. At a flow rate of $1 \mu \mathrm{L} \mathrm{min}{ }^{-1}$ protein digestion is complete and many peptides are matched, resulting in high sequence
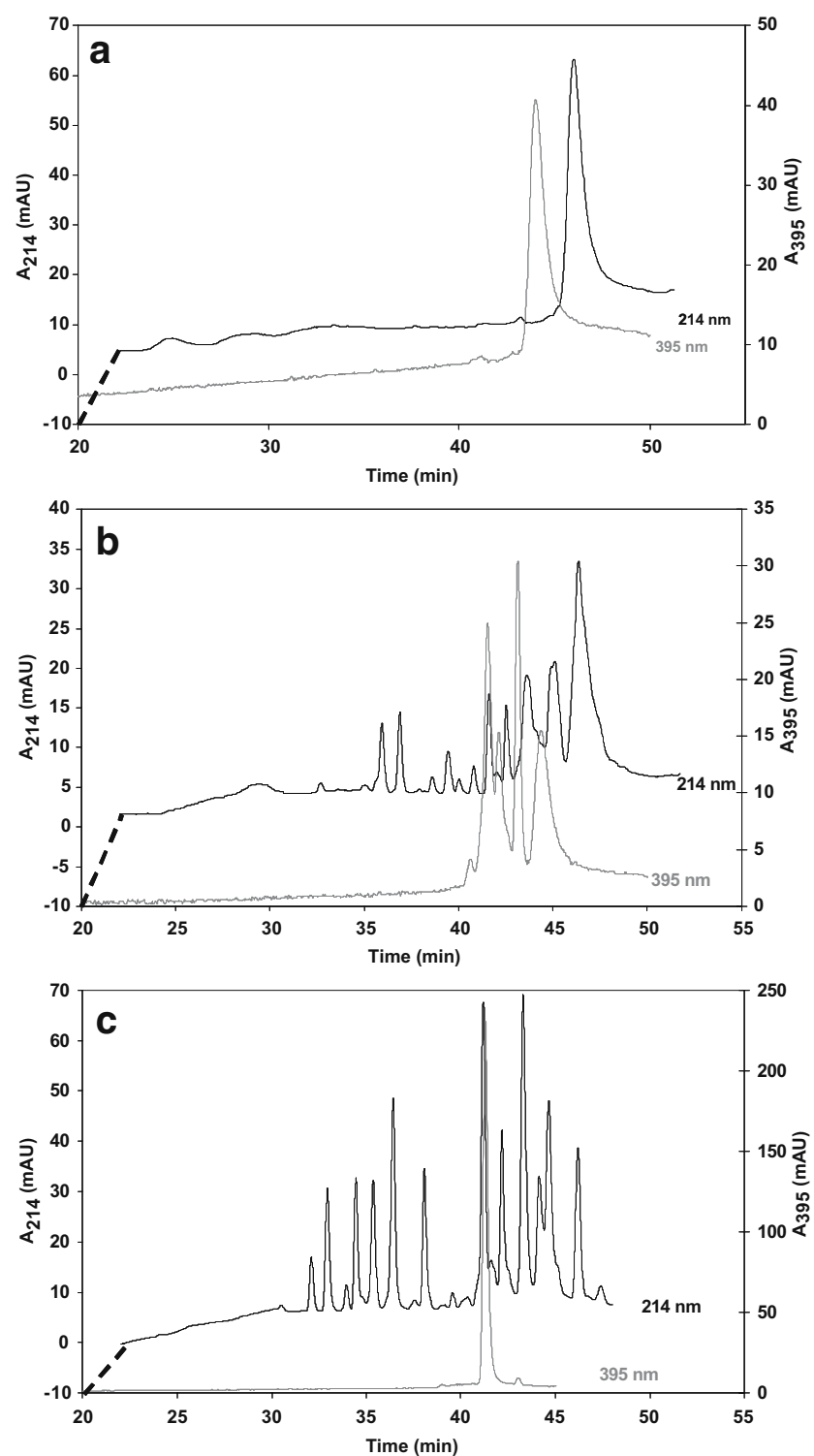

Fig. 4 Chromatograms obtained from injection of 10 pmol horse cytochrome $\mathrm{C}$ in capillary digestion systems monitored at $214 \mathrm{~nm}$ and $395 \mathrm{~nm}$. The experiments were conducted with an APTES-CMDAMD derivatised fused-silica capillary of (a) $510 \times 0.050 \mathrm{~mm}$, not containing trypsin, operated at $1 \mu \mathrm{L} \min ^{-1}$ (blank); (b) $1400 \times$

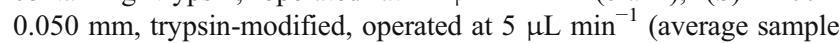
residence time $33 \mathrm{~s}$ ); (c) as (b) but operated at $1 \mu \mathrm{L} \min ^{-1}$ (average sample residence time $165 \mathrm{~s}$ ). For clarity the beginning of the chromatogram displaying the $214 \mathrm{~nm}$ signal is offset as indicated

coverage and Mascot score. With higher flow, and hence decreasing incubation time, the amount of protein that remains undigested increases and consequently fewer peptides are produced and observed. However, even at relatively high flow rates an adequate amount of peptides is still formed and the protein can be identified on the basis of the fragments present. Nevertheless, the ion intensity is low and some peptides are not retrieved as they are below the threshold for auto-MS-MS. Table 3 summarizes the peptides observed and matched using the MS-MS data 
Table 2 General overview of the on-line digestion experiments for cytochrome $\mathrm{C}(n=3)$

\begin{tabular}{llllll}
\hline $\begin{array}{l}\text { flow rate } \\
\left(\mu \mathrm{L} \mathrm{min} \mathrm{min}^{-1}\right)\end{array}$ & $\begin{array}{l}\text { digestion } \\
\text { time }(\mathrm{s})\end{array}$ & $\begin{array}{l}\text { sequence } \\
\text { coverage } \\
(\%)\end{array}$ & $\begin{array}{l}\text { total no } \\
\text { peptides } \\
\text { matched }\end{array}$ & $\begin{array}{l}\text { Mascot } \\
\text { score }\end{array}$ & $\begin{array}{l}\text { undigested } \\
\text { protein }(\%)\end{array}$ \\
\hline 10 & 17 & 66 & 11 & 347 & 60.3 \\
5 & 33 & 66 & 21 & 501 & 31.8 \\
2 & 83 & 66 & 23 & 649 & 18.5 \\
1 & 165 & 87 & 27 & 833 & 0 \\
\hline
\end{tabular}

and a Mascot.database search of proteins digested at a flow rate of $1 \mu \mathrm{L} \mathrm{min}{ }^{-1}$. A base-peak chromatogram (BPC) of the digestion of cytochrome $\mathrm{C}$ under these conditions is shown in Fig. 5a. The MS-MS fragmentation of one of the peptides is presented in Fig. 5 b.

In further experiments horse myoglobin was digested online. This protein is generally regarded as difficult to digest $[15,35]$. When $1 \mu \mathrm{L}$ of a $10 \mu \mathrm{mol} \mathrm{L}{ }^{-1}$ solution in buffer is injected at a flow rate of $1 \mu \mathrm{L} \mathrm{min}{ }^{-1}$ (165 s exposure time), the injected protein is completely digested, as was observed with UV detection (data not shown). Using mass spectrometric analysis, 13 different peptides are observed and matched using the MS-MS data and a Mascot database search, resulting in a sequence coverage of $88 \%$. The matched peptides are summarized in Table 3 and a BPC of the on-line digestion of myoglobin is shown in Fig. 6a, with an MS-MS spectrum of one of the tryptic peptides. Both the degree of digestion and the sequence coverage are adequate compared with other systems that often use a high percentage of modifier to enhance digestion, as the absence of denaturing agents during digestion leads to little or no digestion of myoglobin [35]. Therefore these reactors are generally used for direct infusion into MS or off-line protein digestion as the presence of high concentrations of methanol or acetonitrile in the digestion buffer will seriously impede on-line protein digestion in combination with RP-LC.

Table 3 Peptide fragments observed by MS in the on-line digestion of cytochrome $\mathrm{C}$ and myoglobin The experiments were conducted at $\mathrm{pH} 8.5$ and $37{ }^{\circ} \mathrm{C}$ at a flow rate of $1 \mu \mathrm{L} \mathrm{min}{ }^{-1}$ using a $2.75-\mu \mathrm{L}$ trypsin reactor

\begin{tabular}{|c|c|c|c|c|}
\hline Peptide sequence & Theoretical $\mathrm{m} / \mathrm{z}$ & Experimental $\mathrm{m} / \mathrm{z}$ & Position & Missed cleavage \\
\hline \multicolumn{5}{|l|}{ Cytochrome C (sequence coverage $87 \%$ ) } \\
\hline 1...IFVQKCAQCHTVEK & 1632.8 & $816.9(2+)$ & $9-22$ & 1 \\
\hline 2....HKTGPNLHGLFGR & 1432.8 & $717.1(2+)$ & $26-38$ & 1 \\
\hline 3....TGPNLHGLFGR & 1167.6 & $584.6(2+)$ & $28-38$ & 0 \\
\hline 4....TGPNLHGLFGRK & 1295.7 & $648.6(2+)$ & $28-39$ & 1 \\
\hline 5....KTGQAPGFTYTDANK & 1597.8 & $533.4(3+)$ & $39-53$ & 1 \\
\hline 6....TGQAPGFTYTDANK & 1469.7 & $735.6(2+)$ & $40-53$ & 0 \\
\hline 7....TGQAPGFTYTDANKNK & 1711.8 & $571.4(3+)$ & $40-55$ & 1 \\
\hline 8....GITWKEETLMEYLENPKK & 2208.1 & $736.8(3+)$ & $56-73$ & 2 \\
\hline 9....EETLMEYLENPK & 1494.7 & $748.0(2+)$ & $61-72$ & 0 \\
\hline 10 EETLMEYLENPKK & 1622.8 & $812.1(2+)$ & $61-73$ & 1 \\
\hline 11...YIPGTK & 678.4 & $678.1(1+)$ & $74-79$ & 0 \\
\hline 12...MIFAGIKK & 906.5 & $454.0(2+)$ & $80-87$ & 1 \\
\hline 13...KTEREDLIAYLKK & 1477.8 & $739.6(2+)$ & $88-99$ & 2 \\
\hline 14...TEREDLIAYLKK & 1349.7 & $675.5(2+)$ & 89-99 & 1 \\
\hline 15...EDLIAYLK & 963.5 & $482.6(2+)$ & $92-99$ & 0 \\
\hline 16...EDLIAYLKK & 1091.6 & $546.6(2+)$ & $92-100$ & 1 \\
\hline \multicolumn{5}{|l|}{ Myoglobin (sequence coverage $88 \%$ ) } \\
\hline 1....GLSDGEWQQVLNVWGK & 1814.9 & $908.7(2+)$ & $1-16$ & 0 \\
\hline 2....VEADIAGHGQEVLIR & 1605.8 & $803.6(2+)$ & $17-31$ & 0 \\
\hline 3....VEADIAGHGQEVLIR & 1605.8 & $536.1(3+)$ & $17-31$ & 0 \\
\hline 4....LFTGHPETLEK & 1270.7 & $636.0(2+)$ & $32-42$ & 0 \\
\hline 5....HLKTEAEMK & 1085.6 & $543.5(2+)$ & $48-56$ & 1 \\
\hline 6....HGTVVLTALGGILK & 1377.8 & $689.7(2+)$ & $64-77$ & 0 \\
\hline 7....HGTVVLTALGGILKK & 1505.9 & $502.7(3+)$ & $64-78$ & 1 \\
\hline 8....KKGHHEAELKPLAQSHATK & 2109.1 & $703.7(3+)$ & $78-96$ & 2 \\
\hline 9....KGHHEAELKPLAQSHATK & 1981.0 & $661.1(3+)$ & $79-96$ & 1 \\
\hline 10 GHHEAELKPLAQSHATK & 1853.0 & $618.8(3+)$ & $80-96$ & 0 \\
\hline 11...YLEFISDAIIHVLHSK & 1884.0 & $628.8(3+)$ & $103-118$ & 0 \\
\hline 12...HPGNFGADAQGAMTK & 1500.7 & $751.5(2+)$ & $119-133$ & 0 \\
\hline 13...ALELFRNDIAAK & 1359.8 & $680.6(2+)$ & $134-145$ & 1 \\
\hline 14...YKELGFQG & 940.5 & $471.0(2+)$ & $146-153$ & 1 \\
\hline
\end{tabular}




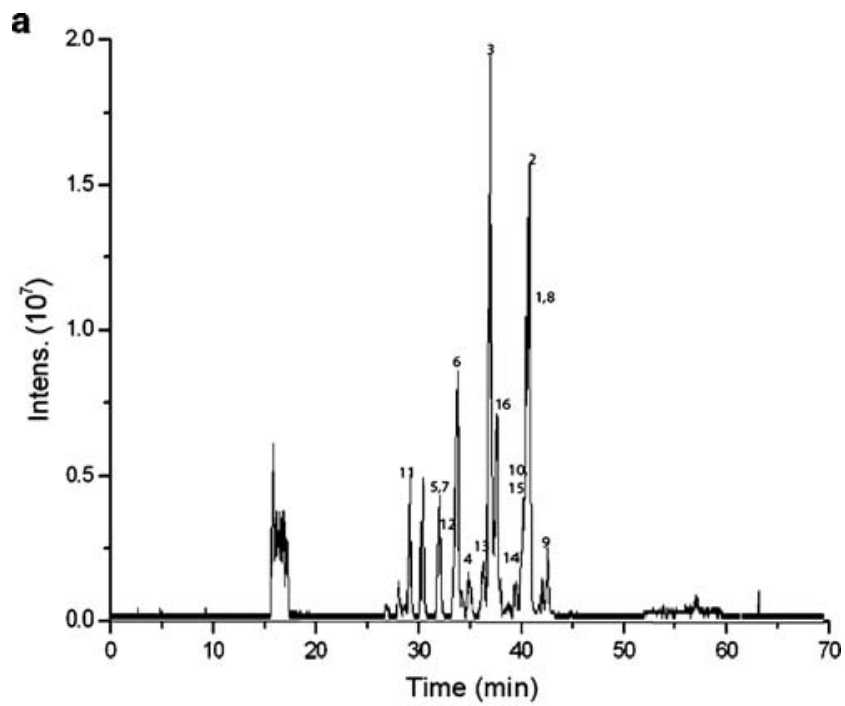

b

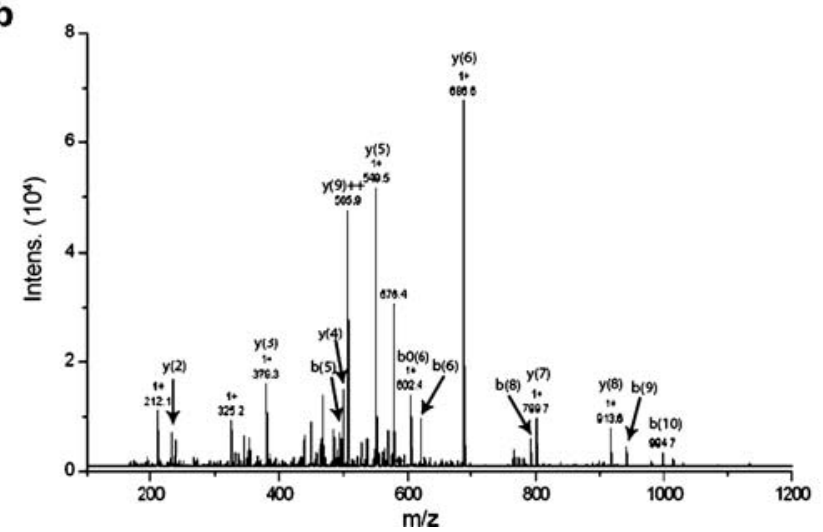

Fig. 5 On-line digestion of $10 \mathrm{pmol}$ cytochrome $\mathrm{C}$ at a flow rate of $1 \mu \mathrm{L} \min ^{-1}$ : (a) base peak chromatogram, the numbers correspond to the matched peptides in Table 3, and (b) MS-MS fragmentation of the peptide TGPNLHGLFGR with $\mathrm{m} / z 584.9$ showing several of the matched fragment ions

Amankwa and Kuhr [30] reported that proteins and peptides adsorb to the capillary surface of their trypsin reactor. Reactor fouling, and as a result sample carry-over, is also observed when trypsin-modified particulate polymers or monoliths are used [36]. Adsorption of proteins and peptides to these relatively hydrophobic columns is prevented by the addition of up to $20 \%$ methanol to the digestion buffer. For dextran-coated surfaces, it is known that the non-specific adsorption of protein is minimal and depends on the character of the oligosaccharide layer [29, 37, 38]. During protein-digestion experiments on SPR sensor surfaces modified identically with the capillary reactors no adsorption during incubation is observed (data not shown). Similarly, during on-line digestion using the dextran coated capillaries, sample adsorption and carry-over are not observed, as repeated sample injections result in identical chromatograms and blank buffer injections do not show peptide fragments. On basis of the latter result and the long lifetime of the reactor, trypsin auto-digestion is probably absent.
The developed IMER has been applied for the digestion of horse cytochrome $\mathrm{C}$ and myoglobin in buffer without prior pretreatment followed by separation and MS-MS sequencing. The time needed to obtain complete protein digestion and sample trapping is 5 min with an average sample residence time of $165 \mathrm{~s}$. The total analysis time, digestion and LC separation, is $65 \mathrm{~min}$. The developed micro-reactor is competitive when compared with other systems used for on-line protein digestion described in literature [13, 14, 39-41]. In the capillary IMERs described by Amankwa and Kuhr [30] and Bossi et al. [34] the complete digestion of native proteins was only obtained when the protein resided in the trypsin-coated capillary for 15-25 min. The peptide separation was carried out with CE in these latter cases.

Many reactors use a protein denaturation step to make the protein more susceptible to proteolytic action. The digestion efficiency can be enhanced by partial denaturation

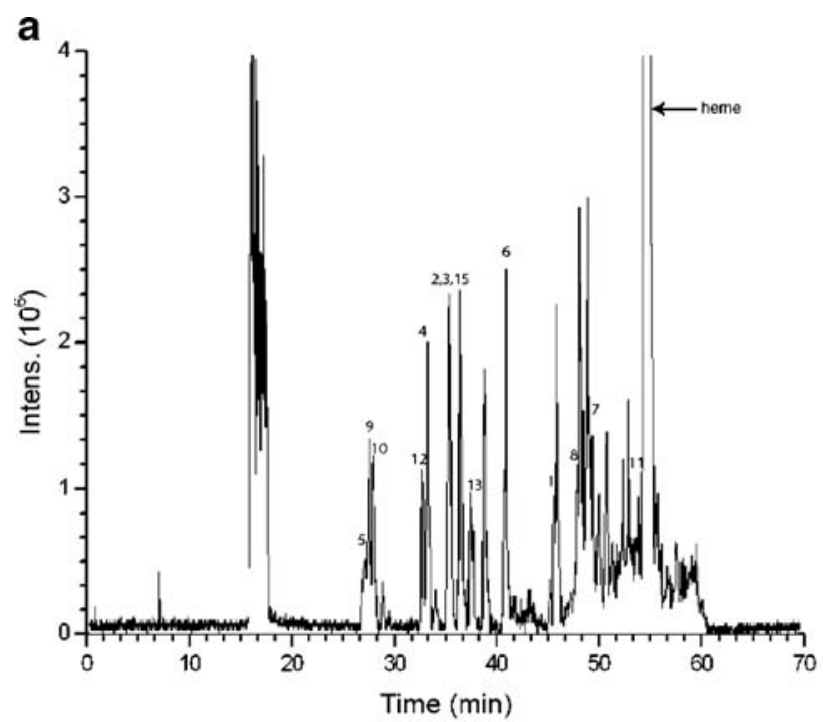

b

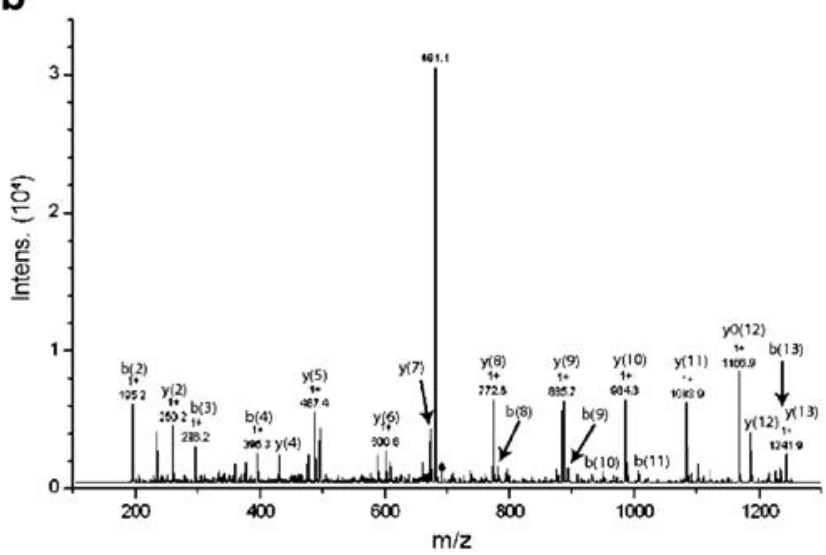

Fig. 6 Results from on-line digestion of $10 \mathrm{pmol}$ myoglobin at a flow rate of $1 \mu \mathrm{L} \min ^{-1}$ : (a) base peak chromatogram, the numbers correspond with the matched peptides in Table 3, and (b) the MS-MS spectrum of the peptide HGTVVLTALGGILK with $\mathrm{m} / \mathrm{z} 689.7$ 
by addition of $35-45 \%$ acetonitrile to the buffer $[11,15,35$, $36]$ or by sonication $[42,43]$. However, the latter has not yet been used in an automated set-up and the presence of high amounts of modifier will make reversed-phase chromatography in a subsequent step for the separation of the fragments produced during protein digestion very difficult. The described reactors were efficient in terms of time needed for digestion and the digestion result, but were, as a rule, used for direct infusion into the MS or used for off-line digestion.

Alternatively, protein denaturation is accomplished using chemicals such as SDS, guanidine $\mathrm{HCl}$ or urea. A recent example is the miniaturized on-line proteolysis-capillary LC system as described by Samskog et al. [12], who employed a $10-\mu \mathrm{L}$ column packed with poroszyme. The sample contained guanidine. $\mathrm{HCl}$ for protein denaturation, and was diluted with buffer, also containing methanol, prior to injection. The total time needed for digestion, trapping, and removal of the high concentration of salt was $15 \mathrm{~min}$. The system needed periodic regeneration to counteract the effects of residual salts in the analyte.

\section{Conclusions}

To study the immobilization of the protein trypsin in a fused-silica capillary, a number of surface modifications was tested. In order to investigate the amount of protein that can be covalently attached to these surfaces, SPR sensor disks are modified with these coatings to mimic the capillary surface. The SPR measurements show that the best results were obtained using a dextran coating with an intermediate layer. The resulting open-tubular trypsin reactors having a $\mathrm{pH}$ optimum of $\mathrm{pH} 8.5$ display a high activity when operated at $37{ }^{\circ} \mathrm{C}$ and are stable for at least two weeks when used continuously.

The capillary reactors show flow-dependent catalysis. For a capillary IMER, the conversion of the insulin B chain increases with decreasing flow and hence a longer residence time. The same is observed for the digestion of horse cytochrome $\mathrm{C}$. The complete digestion of $20 \mathrm{pmol} \mu \mathrm{L}^{-1}$ horse cytochrome $\mathrm{C}$ is observed without the need of protein denaturation, reduction, or alkylation when the average residence time of the protein sample in a $140 \mathrm{~cm} \times 50 \mu \mathrm{m}$ capillary IMER is $165 \mathrm{~s}$. For the proteins used in this study trypsin-reactors were described that were capable of faster digestion using denaturing agents like acetonitrile to enhance the digestion process. However, the presence of such agents would seriously hamper direct analysis of the peptides formed using RPLC and MS. Identification of the proteins cytochrome $\mathrm{C}$ and myoglobin is possible by the tryptic peptides that are produced on-line, separated by micro-RPLC, and analyzed using mass spectrometry with auto MS-MS.
The open-tubular reactor can be produced easily, reproducibly, and inexpensively, and can be used for other applications such as enzyme-inhibitor studies. Future research will focus on the development of miniaturized multidimensional analysis systems employing on-line digestion using these IMERs. The capillary enzyme reactors show no backpressure and seem promising for coupling to other analytical techniques such as capillary electrophoresis and surface plasmon resonance.

\section{References}

1. Courchesne PL, Patterson SD (1999) Identification of proteins by matrix-assisted laser desorption/ionization mass spectrometry using peptide and fragment ion masses. In: Link AJ (ed) Methods in molecular biology: 2-D proteome analysis protocols. Humana Press, Totowa, pp 487-511

2. Henzel WJ, Billeci TM, Stults JT, Wong SC, Grimley C, Watanabe C (1993) Proc Natl Acad Sci USA 90:5011-5015

3. Garbis S, Lubec G, Fountoulakis M (2005) J Chromatogr A 1077:1-18

4. Girelli AM, Mattei E (2005) J Chromatogr B 819:3-16

5. Urban PL, Goodall DM, Bruce NC (2006) Biotechnol Adv 24:42-57

6. Hermanson GT, Mallia AK, Smith PA (1992) Immobilized affinity ligand techniques. Academic Press, San Diego

7. Bonneil E, Waldron KC (2000) Talanta 53:687-699

8. Bonneil E, Mercier M, Waldron KC (2000) Anal Chim Acta 404:29-45

9. Davis MT, Lee TD, Ronk M, Hefta SA (1995) Anal Biochem 224:235-244

10. Hara S, Katta V, Lu HS (2000) J Chromatogr A 867:151-160

11. Slysz GW, Schriemer DC (2003) Rapid Commun Mass Spectrom 17:1044-1050

12. Samskog J, Bylund D, Jacobsson SP, Markides KE (2003) J Chromatogr A 998:83-91

13. Calleri E, Temporini C, Perani E, Stella C, Rudaz S, Lubda D, Mellerio G, Veuthey J-L, Caccialanza G, Massolini G (2004) J Chromatogr A 1045:99-109

14. Calleri E, Temporini C, Perani E, De Palma A, Lubda D, Mellerio G, Sala A, Galliano M, Caccialanza G, Massolini G (2005) J Proteome Res 4:481-490

15. Palm AK, Novotny M (2004) Rapid Commun Mass Spectrom 18:1374-1382

16. Kato M, Inuzuka K, Sakai-Kato K, Toyo'oka T (2005) Anal Chem 77:1813-1818

17. Peterson DS, Rohr T, Svec F, Frechet JMJ (2002) Anal Chem 74:4081-4088

18. Geiser L, Eeltink S, Svec F, Frechet JMJ (2007) J Chromatogr A 1140:140-146

19. Kele M, Guiochon G (2002) J Chromatogr A 960:19-49

20. Slysz GW, Schriemer DC (2005) Anal Chem 77:1572-1579

21. Nadler T, Blackburn C, Mark J, Gordon N, Regnier FE, Vella G (1996) J Chromatogr A 743:91-98

22. Riggs L, Sioma C, Regnier FE (2001) J Chromatogr A 924:359368

23. Licklider L, Kuhr WG, Lacey MP, Keough T, Purdon MP, Takigiku R (1995) Anal Chem 67:4170-4177

24. Ye M, Hu S, Schoenherr RM, Dovichi NJ (2004) Electrophoresis 25:1319-1326

25. Zhao C, Jiang H, Smith DR, Bruckenstein S, Wood TD (2006) Anal Biochem 359:167-175 
26. Krenkova J, Kleparnik K, Foret F (2007) J Chromatogr A 1159:110-118

27. Stenberg E, Persson B, Roos B, Urbanicky C (1991) J Colloid Interface Sci 143:513-526

28. Schwert GW, Takenaka Y (1955) Biochim Biophys Acta 16:570

29. Stigter ECA, De Jong GJ, Van Bennekom WP (2005) Biosens Bioelectron 21:474-482

30. Amankwa LN, Kuhr WG (1992) Anal Chem 64:1610-1613

31. Amankwa LN, Kuhr WG (1993) Anal Chem 65:2693-2697

32. Guo Z, Xu S, Lei Z, Zou H, Guo B (2003) Electrophoresis 24:3633-3639

33. Durgun G, Senay A, Cetinus A (2007) Food Chem 100:964-971

34. Bossi A, Guizzardi L, D'Acunto MR, Righetti PG (2004) Anal Bioanal Chem 378:1722-1728
35. Freije JR, Mulder PPMFA, Werkman W, Rieux L, Niederlander HAG, Verpoorte E, Bisschoff R (2005) J Proteome Res 4:1805-1813

36. Krenková J, Bilkova Z, Foret F (2005) J Sep Sci 28:1675-1684

37. Frazier RA, Matthijs G, Davies MC, Roberts CJ, Schacht E, Tendler SJB (2000) Biomaterials 21:957-966

38. McArthur SL, Mclean KM, Kingshott P, St John HAW, Chatelier RC, Griesser HJ (2000) Colloids Surf B 17:37-48

39. Jiang Y, Lee CS (2001) J Chromatogr A 924:315-322

40. Craft D, Li L (2005) Anal Chem 77:2649-2655

41. Feng S, Ye M, Jiang X, Jin W, Zou H (2006) J Proteome Res $5: 422-428$

42. Licklider L, Kuhr WG (1998) Anal Chem 70:1902-1908

43. López-Ferrer D, Capelo JL, Vázquez J (2005) J Proteome Res 4:1569-1574 